\title{
Analiza błędów popełnionych w tłumaczeniu indonezyjskiego musicalu „Biarkan bintang menari” na język polski.
}

\section{The analysis of errors and mistakes made in the Polish subtitles of an Indonesian musical "Biarkan Bintang Menari”.}

\author{
Daria Zozula \\ INSTYTUT JĘZYKOZNAWSTWA, UNIWERSYTET IM. ADAMA MICKIEWICZA \\ AL. NIEPODLEGŁOŚCI 4, 61-874 POZNAŃ \\ dariazozula@yahoo.com
}

\begin{abstract}
This article is to analyse the errors and mistakes (both technical and linguistic)made in the polish subtitles of an Indonesian musical "Biarkan bintang menari". To fully analyze the errors a new, Indonesian language-specified typology was coined. It allows to explanation of the causes of every type of error found. The analysis is prefaced by a short introduction to Indonesian cinema in a whole and followed by a summary that emphasizes the conclusions. The aim of this paper is to stress the role of proof reading in the process of creating subtitles in a foreign language.
\end{abstract}

\section{Wstęp}

W ciągu ostatnich kilku lat kino azjatyckie zyskało szerokie rzesze wielbicieli wśród Polaków. Jest to widoczne chociażby w repertuarze poznańskich kin, w których już na stałe zagościły wieczory filmów bollywoodzkich, festiwale kina koreańskiego oraz wietnamskiego czy noce japońskich kreskówek organizowane przy współpracy pasjonatów i studenckich kół zainteresowań. Na tym tle jednak kino indonezyjskie nadal pozostaje nieodkryte przez szerszą publiczność, pomimo swej kuszącej odmienności w porównaniu z tym, co jest już znane.

$\mathrm{Z}$ punktu widzenia widza europejskiego filmy produkcji indonezyjskiej, kierowane w głównej mierze do nastolatków, mogą się wydawać naiwne, nudne i wyidealizowane. Ponieważ na ogół są to produkcje niskobudżetowe, ich wykonanie wydaje się być często niedbałe i prymitywne. Ponadto każda indonezyjska produkcja podlega cenzurze, zakazane są pewne „niewygodne” tematy (na przykład korupcja rządu czy rzeź komunistów w 1967) oraz tematy mogące negatywnie wpłynąć na moralność społeczeństwa. Filmy indonezyjskie nie pokazują jednoznacznie przemocy ani seksu, nie znajdziemy $\mathrm{w}$ nich opinii o podłożu politycznym, a niektóre problemy społeczne, takie jak np. bieda i dziecięca prostytucja czy właśnie wydarzenia roku 67 poruszane są w bardzo zawoalowany 
sposób. Równocześnie, ponieważ filmy te rzadko są dystrybuowane do innych krajów azjatyckich czy Europy często ukazują aspekty kultury indonezyjskiej i muzułmańskiej, codzienne rytuały, specyficzne gesty i zwyczaje, co nie ułatwia odbioru całości widzowi spoza tego kręgu kulturowego. Filmy te, tworzone z myślą o odbiorcy indonezyjskim, nie wyjaśniają zazwyczaj, dlaczego w jednym dialogu do tej samej osoby główna bohaterka zwraca się używając aż 3 różnych tytułów honoryfikacyjnych. Nic zatem dziwnego, że dla widza nie obeznanego z kulturą archipelagu indonezyjskiego, filmy te pozostają niezrozumiałe. Jedyną ich nadzieją jest wobec tego tłumacz, którego rolą jest $\mathrm{w}$ tym wypadku nie tylko przetłumaczenie dialogów, ale niejako oddanie w nich całej kultury, w obrębie której dany dialog się toczy.

Subtitling, pod warunkiem, że jest dobrze wykonany, pozwala na zmniejszenie lub wyjaśnienie różnic pomiędzy kulturą ukazaną w filmie a kulturą kraju w którym film jest wyświetlany. W sytuacjach szczególnie trudnych można przed filmem wyświetlić najważniejsze informacje wprowadzające widza w filmowe realia kulturowe. Przez napisy umieszczane w górze ekranu można wytłumaczyć widzowi niejasne rytuały codzienne, a dzięki zastosowaniu techniki domestykacji w tłumaczeniu dialogów uda się zminimalizować uczucie obcości. Jednakże, jeżeli tłumaczenie jest wykonane niekompetentnie, nie tylko nie ułatwi ono odbioru obrazu, ale wręcz go utrudni, wprowadzając dodatkowy zamęt, konsternację i frustrację. Widz bardzo szybko straci zaufanie do tłumaczenia, jeśli zauważy błąd natury językowej lub logicznej. Zamiast na treści i przesłaniu filmu odbiorca skupi uwagę na wyłapywaniu potknięć tłumacza w języku ojczystym i niespójności napisu z tym co widoczne $\mathrm{w}$ filmie, co spowoduje, że najprawdopodobniej się zmęczy, znudzi i opuści kino w połowie seansu.

W dniach 22-28 lutego 2008 roku odbył się równolegle w pięciu największych miastach Polski I Festiwal Filmów Indonezyjskich (FFI). Podczas tego trwającego sześć dni wydarzenia pokazano jedenaście filmów, uważanych za najlepsze filmy produkcji indonezyjskiej z ostatnich pięciu lat. Niestety, głównie ze względu na nieprofesjonalne thumaczenie, filmy te nie spotkały się z ciepłym przyjęciem.

W niniejszej pracy przeanalizuję błędy, które wystąpiły w polskiej wersji napisów do musicalu „Biarkan Bintang Menari” („Gwiazdy grają o miłość). Przeanalizuję przyczyny ich wystąpienia i udowodnię, że polskie tlumaczenie i napisy były głównym powodem opuszczania sali kinowej przez część widzów podczas projekcji.

\section{Problemy techniczne}

Wykonanie napisów do wszystkich filmów pokazywanych podczas festiwalu zostało zlecone studentom od trzech lat uczącym się języka indonezyjskiego, studiujących etnolingwistykę na Uniwersytecie im. A. Mickiewicza w Poznaniu.

Ta decyzja była spowodowana wieloma czynnikami. Po pierwsze grupa studentów była jedynym tak dużym skupiskiem osób (dziewięć studentek), które w stopniu zaawansowanym opanowały język indonezyjski i dodatkowo posiadały wiedzę językoznawczą oraz niektóre $\mathrm{z}$ osób uczęszczały na warsztaty thumaczeniowe prowadzone jako fakultet na etnolingwistyce. Poza tym studenci traktując to zlecenie jako praktykę nie pobrali honorarium, zastrzegając jednocześnie, że wymagają dodatkowej zewnętrznej korekty, ponieważ jest to dla nich pierwsza tego typu praca $\mathrm{z}$ kombinacją języków indonezyjski-polski. 
Daria Zozula: Analiza błędów popetnionych w tlumaczeniu indonezyjskiego musicalu „Biarkan bintang menari” na język polski.

Jedenaście przyjętych do tłumaczenia filmów przydzielono studentkom losowo. Tłumaczowi „Biarkan Bintang Menar"” dostarczono tylko kopię filmu i wymagano, aby dokonał tłumaczenia ze słuchu i przekształcił tłumaczenie w napisy opatrzone czasami rozpoczęcia i końca wyświetlania danego napisu. Tłumacz zdając sobie sprawę ze swojego braku kompetencji w dziedzinie synchronizacji napisów z materiałem filmowym nie podjął się takiego zadania. Dostarczono mu więc transkrypcję wykonaną przez Indonezyjczyków mieszkających w Polsce oraz wersję angielską napisów $\mathrm{w}$ formacie pliku tekstowego, opatrzoną czasami wyświetlania. To znacznie przyspieszyło pracę, ponieważ jedynym zadaniem tłumacza $\mathrm{w}$ kwestii technicznej było właściwie wpisanie napisów polskich $\mathrm{w}$ miejsce angielskich. Tłumacz nie posługiwał się wersją angielską do weryfikacji wersji polskiej, ponieważ nie posługuje się on płynnie tym językiem, w dwóch przypadkach zostawił wersję angielską napisu ponieważ nie wiedział jak dane napisy przetłumaczyć i miał nadzieję, że zostanie to poprawione podczas korekty zewnętrznej, co niestety nie nastąpiło.

Niestety, młody niedoświadczony tłumacz, nie znał podstawowych zasad i technik stosowanych $\mathrm{w}$ thumaczeniu audiowizualnym, w rezultacie czego $\mathrm{w}$ napisach występują błędy natury technicznej, mające również duży wpływ na jakość całości:

- za krótki czas wyświetlania napisu,

- pominięcie napisu,

- połączenie dwóch podpisów w jeden.

Tymczasem wystarczyło znać tylko kilka reguł ogólnie znanych w środowiskach tłumaczy audiowizualnych, o których w swojej książce „Tłumaczenie Audiowizualne" pisze pani Teresa Tomaszkiewicz oraz które są szeroko dyskutowane na forach tłumaczy (na przykład www.mlingua.pl) by tych problemów uniknąć:

- napisy powinny zajmować 2/3 szerokości ekranu i być wyśrodkowane,

- powinny zajmować nie więcej niż $15 \%$ wysokości ekranu,

- wyświetla się maksymalnie 32 do 40 liter w linii (na potrzeby kina) i 28 do 38 liter w linii na potrzeby telewizji,

- wyświetlane są jednorazowo maksymalnie dwie linie, jedna jest wyświetlana przez maksymalnie 4 sekundy, dwie od czterech do ośmiu sekund; jeśli czas wyświetlania napisu byłby krótszy, widz mógłby nie zdążyć go przeczytać, jeśli byłby dłuższy, istnieje niebezpieczeństwo ponownego przeczytania napisu,

- tekst musi być podzielony na jednostki semantycznie i syntaktycznie logiczne, tzn. nie należy oddzielać przyimków od rzeczowników, rozdzielać czasowników złożonych, przymiotników z rzeczownikami itp., ponieważ może to utrudniać zrozumienie tekstu.

Niestety, tłumacz nie dysponował ani tą podstawową wiedzą na temat technicznego aspektu tłumaczenia, ani wiedzą na temat strategii tłumaczeniowych (czyli całościowego podejścia do tłumaczenia) stosowanych przy subtitlingu czy w tłumaczeniu pisemnym w ogóle, przede wszystkim zapomniał o ostatecznej korekcie i wizualizacji filmu z napisami.

Tłumacz wstępnie przetłumaczył transkrypcję dialogów wpisując od razu wersję polską w miejsce napisów angielskich, napisy nie przeszły etapu weryfikacji, wizualizacji czy korekty zewnętrznej, dlatego sprawiały raczej wrażenie wersji roboczej, niż skończonego produktu. Tymczasem wielu błędów można by uniknąć, 
gdyby tłumacz jeszcze raz rozważył swoje decyzje tłumaczeniowe, a właściwie można by uniknąc prawie wszystkich gdyby przed dystrybucją napisów dokonano ich sprawdzenia i korekty. Jednakże, pomimo podania przed napisami nazwiska zarówno tłumacza jak i osoby wykonującej korektę, korekta zewnętrzna, za którą odpowiedzialny był zleceniodawca, nie została wykonana.

\section{Typologia błędów}

Tłumacz pracujący nad przekładem audiowizualnym powinien być wszechstronny, po części językoznawca, kulturoznawca, glottodydaktyk , filmoznawca a nawet psycholog, przewidujący reakcje widowni na dany tekst. Dlatego translatoryka jest dziedziną eklektyczną. Dlatego też przyczyny błędów powstających podczas tłumaczenia mają najróżniejsze źródła. Mogą one wynikać z braków kompetencji językowej tłumacza, z niezrozumienia intencji autora, z nieznajomości dziedziny, z braku odpowiedniej metody przekładowej, z mylnego ocenienia wiedzy odbiorcy, z nieuwagi tłumacza a także $\mathrm{z}$ wielu innych przyczyn. Jeśli mowa o tłumaczeniu audiowizualnym należy także wziąć pod uwagę przyczyny pozajęzykowe, związane $\mathrm{z}$ aspektem technicznym dubbingu czy subtitlingu.

Jednakże, według Dzierzanowskiej (1990), która analizowała teksty tłumaczone $\mathrm{z}$ języka polskiego na angielski, przyczyną błędów występujących $\mathrm{w}$ thumaczeniu jest zazwyczaj transfer negatywny, czyli interferencja. Jest to termin zaczerpnięty $\mathrm{z}$ lapsologii glottodydaktycznej Grucza(1978:17) definiuje interferencję w następujący sposób: „Tam, gdzie między uprzednio zinternalizowanym materiałem językowym a materiałem przyswajanym aktualnie zachodzi identyczność strukturalna, będziemy mieli do czynienia z tzw. transferem pozytywnym, natomiast tam, gdzie zachodzi odmienność strukturalna, może wystąpić zjawisko tzw. transferu negatywnego, który w lingwistyce i glottodydaktyce nazywa się zwykle interferencją. Interferencja jest więc zjawiskiem niepożądanym, prowadzi bowiem do tworzenia błędnych struktur i błędnych realizacji”. Jeśli pod wpływem jednego języka powstają błędy w drugim języku to jest to interferencja interlingwalna (zewnętrzna). Natomiast, jeśli błąd powstaje pod wpływem struktur tego samego języka mamy do czynienia $\mathrm{z}$ interferencją intralingwalną (wewnętrzną).

Te dwa rodzaje są przyczyną następujących błędów:

- błędy ortograficzne (z podziałem na podgrupy: pisownia i interpunkcja),

- błędy formy i konstrukcji gramatycznej (z podziałem na podgrupy: formy morfologiczne, elementy struktury grupy wyrazowej, elementy struktury zdania),

- błędy szyku wyrazów (z podziałem na podgrupy: zdanie, grupa wyrazowa),

- błędy leksykalne (z podziałem na podgrupy: wyraz, grupa wyrazowa),

- błędy polegające na braku adekwatności sytuacyjnej, stylistycznej i semantycznej.

Klasyfikacja tu zastosowana jest oparta na klasyfikacji Dzierżanowskiej, przedstawia się ona następująco:

Błędy językowe:

- błędy ortograficzne i interpunkcyjne;

- błędy stylistyczne;

- błędy leksykalne i składniowe 
Daria Zozula: Analiza błędów popetnionych w thumaczeniu indonezyjskiego musicalu „Biarkan bintang menari” na język polski.

- nonsens

- pozostałe błędy

Niektóre kategorie zostały połączone, ponieważ napotkane błędy można by zakwalifikować do obu kategorii, lub w jednym napisie występują oba błędy. Ponieważ autorka niniejszej pracy miała podczas jej pisania możliwość kontaktu z tłumaczami analizowanego materiału

(sama jest tłumaczem jednego z filmów) można było przez konsultacje określić dokładnie przyczyny niewłaściwych decyzji tłumaczeniowych. Umożliwiło to podzielenie dodatkowo każdej kategorii na podkategorie ze względu na przyczyny powstania danego błędu. W napisach wystąpiły także błędy techniczne wynikające z problemów edycyjnych, na przykład połączenie dwóch napisów lub zbyt krótki czas wyświetlenia napisu. Te błędy nie będą w niniejszej pracy szerzej omawiane. 


\section{Błędy ortograficzne i interpunkcyjne}

$\mathrm{W}$ analizowanych napisach nie wystąpiło wiele błędów ortograficznych (1 błąd na $30 \mathrm{z}$ wszystkich błędów). Błędów interpunkcyjnych wystąpiło niewiele, a były to zazwyczaj pominięte przecinki lub nadużycia wielokropka i nie miały one większego wpływu na odbiór całości.

Błąd ortograficzny:

\begin{tabular}{|c|c|c|}
\hline Oryginal & Tłumaczenie & Powinno byé \\
\hline Itu gak adil! & To nie sprawiedliwe! & To niesprawiedliwe! \\
\hline
\end{tabular}

Wjęzyku polskim partykułe "nie" z przymiotnikami piszemy łącznie.

\section{Błędy stylistyczne}

Poniższy fragment dialogu pojawił się na ekranie w dwóch liniach na 2 sekundy. Według Tomaszkiewicz napisy do filmów powinny pojawiać się w maksymalnie dwóch liniach na raz, w obu liniach powinno się umieszczać od 32 do 40 liter. W przypadku, gdy napis ma tylko jedną linię, powinien on być widoczny na ekranie przez 4 sekundy, a gdy składa się on z dwóch linii od 4 do 6 sekund.

Poniższy podpis składa się w pierwszej linii z siedmiu liter, a w drugiej z liter trzydziestu i jest widoczny dla widza przez dwie sekundy. Jest to zdecydowanie za krótki czas, by widz zdążył przeczytać obie linie. Gdyby zdążył, zapewne zauważyłby błąd stylistyczny, który pojawił się w drugiej linii.

Menyebalkan jest wyrazem o znaczeniu pejoratywnym, Echols w słowniku indonezyjsko-angielskim tłumaczy je jako „nosy”, czyli „wścibski”. Przetłumaczenie tego słowa jako „dociekliwa” i dodatkowo zestawienie go z wyrazem "laska” pochodzącym z rejestru niskiego języka jest więc błędne, ponieważ „dociekliwy” ma znaczenie pozytywne i dodatkowo pochodzi z rejestru wysokiego.

\begin{tabular}{|c|c|c|}
\hline Oryginal & Tłumaczenie & Powinno byé \\
\hline $\begin{array}{l}\text { - Aku cuma.. } \\
\text {-Jangan menyebalkan jadi } \\
\text { cewek. }\end{array}$ & $\begin{array}{l}\text { - Ja tylko... } \\
\text { - Przestań być taką dociekliwą } \\
\text { laską. }\end{array}$ & $\begin{array}{l}\text { - Ja tylko.. } \\
\text { - Nie bądź } \\
\text { wścibska. }\end{array}$ \\
\hline
\end{tabular}

\section{Błędy leksykalne i składniowe}

Błędy leksykalne są największą grupą błędów popełnionych w tłumaczeniu Biarkan Bintang Menari, jest ich aż 7 na 30 wszystkich błędów. Przyczyn tak dużej ich ilości można się doszukiwać w specyfice języka indonezyjskiego. Poszczególne błędy i ich przyczyny będą omawiane osobno.

\section{słowa}

\section{Błędy wynikające $\mathrm{z}$ niewłaściwego wyboru znaczenia}

a) Język indonezyjski przepełniony jest homofonami i homonimami, często znaczenie jakiegoś słowa nie wynika $\mathrm{z}$ konstrukcji zdania, a z kontekstu sytuacyjnego.

Przykłady:

\begin{tabular}{l|l|l} 
Oryginał & Tłumaczenie & Powinno być
\end{tabular}


Daria Zozula: Analiza błędów popetnionych w thumaczeniu indonezyjskiego musicalu „Biarkan bintang menari” na język polski.

\begin{tabular}{|c|c|c|}
\hline Gagal! & Oblałam! & Beznadzieja! \\
\hline
\end{tabular}

$\mathrm{W}$ potocznym języku indonezyjskim $\mathrm{w}$ zasadzie nie występują indykatory mówiące o tym, czy dane słowo jest czasownikiem (w literackim języku indonezyjskim, aby stworzyć czasownik należy dodać przedrostek me przed dany przymiotnik lub rzeczownik, czego nie stosuje się w rozmowach codziennych), komunikacja więc opiera się głównie na kontekście sytuacyjnym.

Słowo gagal może występować w zależności od sytuacji komunikacyjnej i pozycji w zdaniu jako:

- czasownik: menggagalkan/gagal ujian - oblać egzamin,

- przymiotnik: ujian gagal - oblany egzamin, acara gagal - nieudany plan,

- wyrażenie niezadowolenia $\mathrm{w}$ slangu młodzieżowym, znaczenie podobne do „ale dno!”, „bez sensu!” „beznadzieja!” w języku polskim.

$\mathrm{Z}$ kontekstu sytuacji komunikacyjnej, $\mathrm{w}$ której to zdanie zostało wypowiedziane (dwie nastolatki malują się przed lustrem w pokoju jednej z nich) jasno wynika, że chodziło o znaczenie trzecie, dziewczyna mówiąca „gagal”, wyraziła w ten sposób swoją negatywną opinię na temat rezultatu wielogodzinnego nakładania makijażu.

b)

\begin{tabular}{|l|l|l|}
\hline Oryginal & Tłumaczenie & Powinno być \\
\hline $\begin{array}{l}\text { Gue barusan nge-check di } \\
\text { gudang. Stock masih } \\
\text { banyak banget! }\end{array}$ & $\begin{array}{l}\text { Widziałem właśnie } \\
\text { ogromną dostawę wa w w magazynie! Mamy } \\
\text { hurtowni. }\end{array}$ & $\begin{array}{l}\text { Sprawdem prą chwilą } \\
\text { jeszcze całe mnóstwo! }\end{array}$ \\
\hline
\end{tabular}

Rozmówcy są pracownikami budowlanymi, a przedmiotem ich rozmowy jest cement, który należy zamówić. Osoba wypowiadająca to zdanie chwilę przedtem kłóci się z kierownikiem, że nie ma potrzeby kupować więcej cementu, bo starczy ten, który już mają.

Słowo gudang oznacza skład, magazyn, hurtownię stodołę, kopalnię. Przetłumaczenie go jako „hurtownia” mogło być spowodowane sąsiedztwem anglicyzmu stock, którego pierwsze znaczenie to „towar”.

c) Podobny błąd wystąpił w setnej minucie filmu:

\begin{tabular}{|c|c|c|}
\hline oryginal & tłumaczenie & Powinno byé \\
\hline $\begin{array}{l}\text {-Kok bisa sih orang di sini } \\
\text { hidun kavak oitu? }\end{array}$ & -Jak ludzie mogą tak żyć & \begin{tabular}{|l}
-Jak ludzie mogą tu żyć? \\
-Kto powiedział, że mv tu
\end{tabular} \\
\hline $\begin{array}{l}\text { Siapa bilang di sini kita } \\
\text { hidup? } \\
\text { Kita cuma nafas lagi Ney. }\end{array}$ & $\begin{array}{l}\text {-Kto powiedzial, że my tu } \\
\text { mieszkamy... } \\
\text { oddychamy, to wszystko. }\end{array}$ & $\begin{array}{l}\text { żyjemy? Tylko } \\
\text { oddychamy, to wszystko. }\end{array}$ \\
\hline
\end{tabular}

Bezokolicznik hidup w zależności od kontekstu posiada kilka znaczeń:

- żyć, mieszkać - odnoszące się do istot żywych, podobnie jak angielski czasownik to live 
- być włączonym -odnoszące się do sprzętów elektrycznych.

Z kontekstu sytuacyjnego oraz otoczenia zdania wynika, że chodzi o życie, a nie o mieszkanie. Przetłumaczenie hidup jako mieszkania, w sytuacji gdzie słowo hidup jest widocznie skontrastowane ze słowem nafas (oddychać) prowadzi do nonsensu.

W oryginale był to kluczowy dialog, o wydźwięku filozoficznym. Jedna z bohaterek wyraża opinię, że życie w Dżakarcie nie jest prawdziwym życiem. Błędne wybranie znaczenia tylko jednego słowa w całej wypowiedzi skutkuje utraceniem całości dramatyzmu tej wypowiedzi.

Poza tym w cytowanym wyżej fragmencie dialogu wystąpił błąd składniowy:

Jak ludzie mogą tak żyć jak tu?

Kok bisa sih orang di sini hidup kayak gitu?

W oryginale zdanie to brzmi dziwnie, ponieważ wprowadzone są elementy indonezyjskiego języka potocznego (bahasa sehari-hari). W języku indonezyjskim literackim (bahasa baku) brzmiałoby ono:

Bagaimana orang di sini bisa hidup seperti itu?

gdzie pary kok bisa sih i bagaimana, oraz kayak gitu i seperti ini mają semantycznie to samo znaczenie, jednak czynnikiem rozróżniającym je jest rejestr.

Nie ma natomiast w tym zdaniu porównania wprowadzonego przez tłumacza w podpisach:

- Jak ludzie mogą tak żyć jak tu?

W języku polskim powyższe zdanie brzmi raczej sztucznie, powoduje to jeszcze większe zakłócenia odbioru.

\section{Sens przeciwny}

\begin{tabular}{|c|c|c|}
\hline Oryginal & Tłumaczenie & Powinno byé \\
\hline $\begin{array}{l}\text { Selamat datang engkaulah } \\
\text { pangeran ku. }\end{array}$ & Witaj księżniczko. & Witaj książę. \\
\hline $\begin{array}{l}\text { Putri sejati tak akan } \\
\text { berubah menjadi satu } \\
\text { ekor kelinci. } \\
\text { Bila nanti sang pangeran } \\
\text { melihat tak akan dia jatuh } \\
\text { hati }\end{array}$ & $\begin{array}{l}\text { Prawdziwy książę nigdy } \\
\text { nie zamieniłby się w } \\
\text { królika. } \\
\text { Bo gdyby zobaczyła to } \\
\text { księżniczka } \\
\text { Nie mógłby się nigdy w } \\
\text { niej zakochać. }\end{array}$ & $\begin{array}{l}\text { Prawdziwa księżniczka } \\
\text { nigdy nie zamieniłaby się } \\
\text { w królika. } \\
\text { Bo gdyby zobaczył to } \\
\text { książę, } \\
\text { nie mógłby się nigdy w } \\
\text { niej zakochać. }\end{array}$ \\
\hline
\end{tabular}

W pierwszym przykładzie są to słowa dziewczynki pozdrawiającej chłopca stojącego przed nią. Drugi jest reakcją chłopca na stwierdzenie dziewczynki mówiącej, że zamieni się w królika. Nie ma tam mowy o księciu zamieniającym się w to zwierzę.

Te błędy leksykalne wynikają z pomylenia przez tłumacza znaczeń słów putri („księżniczka”) i pangeran ( „książę”). Jest to zapewne wynik niedostatecznej 
Daria Zozula: Analiza błędów popetnionych w tlumaczeniu indonezyjskiego musicalu „Biarkan bintang menari” na język polski.

wiedzy językowej oraz braku korekty po przetłumaczeniu wstępnym tekstu. W wyniku zamiany znaczeń słów pangeran i putri nastąpiła poważna zmiana znaczenia całej wypowiedzi, pozostająca jednak niezauważalna dla widza. W oryginale książę nie zakochałby się w księżniczce, bo miałaby ogon. Z tłumaczenia natomiast wynika, że gdyby księcia królika zobaczyła księżniczka, on nie mógłby się w niej zakochać. Niemożność zakochana się księcia w księżniczce wynika z faktu ujrzenia go pod postacią króliczą. Jest to absurdalne i byłby to poważny błąd, ale że jest to część piosenki i ten temat nie jest $\mathrm{w}$ dalszej części filmu kontynuowany, błąd ten nie zaburza odbioru. W innym przypadku gdyby pojawił się sens przeciwny, na pewno wystąpiłoby zaburzenie odbioru. Ilustruje to przykład poniżej:

\begin{tabular}{|l|ll|c|}
\hline \multicolumn{1}{|c|}{ Oryginał } & \multicolumn{2}{|c|}{ Tłumaczenie } & Powinno byćc \\
\hline $\begin{array}{l}\text { Saya yang kasih contekan } \\
\text { ke dia. }\end{array}$ & $\begin{array}{l}\text { To ja sóciągałam z z jej } \\
\text { notatek }\end{array}$ & To ja dałam jej ściągać \\
\hline
\end{tabular}

Jest to poważny błąd, tym bardziej, że zauważalny dla widza. Według wszelkich przesłanek powodem jego popełnienia nie była niewiedza, czy wieloznaczność, ale zwykłe niechlujstwo i niedbalstwo. Kontekst sytuacyjny i samo zdanie jasno pokazują, kto od kogo ściągał. Tego typu błąd jest wprost niemożliwy do przeoczenia przez widza i jeśli nie spowoduje niezrozumienia akcji filmu, to na pewno zaowocuje przynajmniej podważeniem profesjonalizmu tłumacza.

\section{Kalki językowe}

\begin{tabular}{|c|c|c|}
\hline Oryginal & Tłumaczenie & Powinno być \\
\hline Ga boleh punya aksesori! & Akcesoria są zabronione! & Żadnej biżuterii! \\
\hline
\end{tabular}

Mówiąc powyższe zdanie chłopak każe dziewczynie schować naszyjnik do torebki. $\mathrm{W}$ potocznym języku indonezyjskim słowo biżuteria (penghiasan) coraz częściej zastępuje zaczerpnięte z angielskiego słowo aksesori, oznaczające wszelkie dodatki do ubrań np. buty, torebki, zegarki, naszyjniki kolczyki itp.

Według Uniwersalnego Stownika Języka Polskiego PWN natomiast „akcesoria” to liczba mnoga od akcesorium, które oznacza „narzędzie lub inny drobny przedmiot potrzebny do wykonywania jakiejś czynności, jakiegoś rzemiosła". Również w potocznym języku polskim słowo to nie jest używane w stosunku do elementów biżuterii. Dlatego powyższe zdanie jest błędne.

\section{Błędy leksykalne prowadzące do nonsensu}

\begin{tabular}{|l|l|l|}
\hline \multicolumn{1}{|c|}{ Oryginal } & Tłumaczenie & Powinno być \\
\hline Ini OSPEK! & To zaproszenie! & Jesteście kotami! \\
\hline
\end{tabular}

W przykładzie pierwszym OSPEK to akronim od Orientasi Studi dan Pengenalan Kampus, oznaczający dzień orientacyjny na uniwersytecie. Podczas tego dnia tradycją jest męczenie i znęcanie się starszych studentów nad pierwszorocznymi, często dochodzi do aktów przemocy słownej i fizycznej. W filmie pokazana jest scena, w której starszy student popędza przerażonych pierwszoroczniaków, 
popycha ich i krzyczy na nich tłumacząc swoje postępowanie tym, że jest to właśnie OSPEK.

Można by to przetłumaczyć jako „kotowanie”, lub „kocenie”, pomimo tego, że Uniwersalny Stownik Języka Polskiego PWN nie podaje żadnego z tych słów w znaczeniu adekwatnym do OSPEK. Jednakże słowa te są powszechnie używane przez polską młodzież. Tłumacz mógł również przetłumaczyć to słowo jako „chrzest”, lub w ostateczności nie tłumaczyć wcale i mieć nadzieję, że widz sam się zorientuje, co się dzieje. Błędne tłumaczenie znów zaowocowało nonsensem, zwłaszcza, że jest ono powtarzane kilkakrotnie i za każdym razem tłumaczone jako „zaproszenie”.

Scena pokazywana podczas wyświetlania tego napisu nie ma nic wspólnego z zaproszeniem, pomyłka nie może też wynikać z podobieństwa morfologicznego słów kotowanie (OSPEK ) i zaproszenie (undangan).

\begin{tabular}{|l|l|l|}
\hline \multicolumn{1}{|c|}{ Oryginał } & \multicolumn{1}{|c|}{ Tłumaczenie } & \multicolumn{1}{c|}{ Powinno być } \\
\hline -Kau bisa nggak tadi? & -Może zrobimy test!? & -Jak Ci poszło? \\
-Kamu nanya, atau & -To ma być pytanie, czy & -To ma być pytanie, czy \\
ngejek? & żartujesz? & żartujesz? \\
-Gue udah janji musti & -Mam zaproszenie na & -Muszę się pospieszyć, \\
buru buru! & polowanie! & umówiłam się z kimś! \\
\hline
\end{tabular}

Scena, w której rozgrywa się wyżej przytoczony dialog, następuje zaraz po scenie, w której podczas egzaminu jedna $\mathrm{z}$ bohaterek prosiła drugą o pomoc $\mathrm{W}$ rozwiązywaniu testu, jednak tamta nie chce dać jej ściągi. Po egzaminie dziewczyna, która nie pomogła swojej koleżance podchodzi do niej i pyta, jak jej poszło. W napisie widzimy zupełnie inną treść. Niestety, nic nie wskazuje na przyczynę popełnienia tego błędu. Może to być jedynie dodanie informacji lub niezrozumienie sensu wypowiedzi przez tłumacza.

W dalszej części tego samego dialogu wystąpił błąd, który często zdarza się początkującym uczniom języka indonezyjskiego. Jak już zostało powiedziane wcześniej, wiele słów indonezyjskich ma kilka znaczeń semantycznych. Co więcej, przez dodanie odpowiednich przyrostków do słowa wyjściowego otrzymujemy słowa semantycznie dalekie od słowa, z którego powstały.

Bezokolicznik buru ma to samo znaczenie, co polski bezokolicznik „gonić, przez dodanie przedrostka ber- można zmodyfikować znaczenie tego bezokolicznika i powstanie berburu czyli polować.

Reduplikacja bezokolicznika buru spowoduje natomiast kolejną zmianę znaczenia i powstanie buru buru czyli śpieszyć się. Zdanie „Mam zaproszenie na polowanie!” jest tak dalekie od oryginału, że aż w tym kontekście sytuacyjnym staje się absurdalne.

\section{Nonsens}

Nonsens według Dzierżanowskiej jest najpoważniejszym błędem występującym w tłumaczeniu. Polega on na całkowitej zmianie znaczenia tekstu, w wyniku czego powstaje tekst absurdalny.Z reguły przyczyną nonsensu są inne nakładające się na siebie błędy przekładowe, takie jak dosłowne tłumaczenie, opuszczenie, pominięcie lub dodanie informacji i inne. 
Daria Zozula: Analiza błędów popetnionych w thumaczeniu indonezyjskiego musicalu „Biarkan bintang menari” na język polski.

W tłumaczeniu filmu na język polski tłumacz popełnił bardzo dużo błędów zaliczanych do kategorii nonsensu. Zapewne to spowodowało, że część widzów opuszczała kino w trakcie projekcji, ponieważ nonsensy wywołały u nich irytację $\mathrm{z}$ niezrozumienia filmu.

Poniżej przytaczam części piosenki śpiewanej przez głównego bohatera. Tłumacz zapewne chciał zachować lirykę tekstu, niestety, w tym celu przetłumaczył dosłownie i „po kawałku” tekst oryginalny. Rezultatem tych działań jest śmiesznie brzmiący i absurdalny tekst, nie mający wiele wspólnego z poprawną polszczyzną. W języku polskim nie występuje mianowicie wyrażenie „zdmuchnąć coś tam i z powrotem” ani też „łamać coś palcem marzeń” a już na pewno nie możemy „widzieć rogiem oczu” ani też mieć „otwartego głosu”. Jest to dowód na niekompetencję tłumacza i pewną nieznajomość poetyki, a konkretnie środków poetyckiego wyrazu, tak charakterystyczną dla piosenek musicalowych.

\begin{tabular}{|c|c|c|}
\hline Oryginal & Tłumaczenie & Powinno być \\
\hline $\begin{array}{l}\text { Dari sudut mataku ku } \\
\text { lihat laju langkah kaki mu } \\
\text { Tuju dinding hati }\end{array}$ & $\begin{array}{l}\text { W rogu swoich oczu mogę } \\
\text { widzieć twoje kroki } \\
\text { Obejdź ścianę naokoło } \\
\text { mojego serca }\end{array}$ & $\begin{array}{l}\text { Kątem oka widzę Cię } \\
\text { Stoisz przy ścianie } \\
\text { okalającej moje serce. }\end{array}$ \\
\hline $\begin{array}{l}\text { Yang kau coba dembus } \\
\text { dengan jari mimpi mimpi } \\
\text { mu }\end{array}$ & $\begin{array}{l}\text { Próbujesz ją złamać } \\
\text { palcem swoich marzeń }\end{array}$ & $\begin{array}{l}\text { Próbujesz ją rozbić } \\
\text { marzeniami, }\end{array}$ \\
\hline $\begin{array}{l}\text { Yang telah berlalu dan tak } \\
\text { berlaku }\end{array}$ & się nie udało & dziecinnymi i naiwnymi. \\
\hline $\begin{array}{l}\text { Hidup ini cukup lama buat } \\
\text { mata ku terbuka }\end{array}$ & $\begin{array}{l}\text { Żyłem wystarczająco } \\
\text { długo by zobaczyć } \\
\text { Jakie życie jest naprawdę. }\end{array}$ & $\begin{array}{l}\text { Żyję wystarczająco długo } \\
\text { by zrozumieć, }\end{array}$ \\
\hline Kini ku mengerti & Teraz zrozumiałem & że miłość, \\
\hline $\begin{array}{l}\text { Bahwa segala cinta yang } \\
\text { pernah ada di hati } \\
\text { Kan melemakan dan } \\
\text { menghancurkan }\end{array}$ & $\begin{array}{l}\text { Że każda miłość zawsze w } \\
\text { moim sercu. } \\
\text { Jest krucha i niszczy się }\end{array}$ & $\begin{array}{l}\text { przynosi tylko ból } \\
\text { cierpienie. } \\
\text { Odgrodziłem się od niej. }\end{array}$ \\
\hline $\begin{array}{l}\text { Dan kini kau ingin, } \\
\text { dengan mudahnya } \\
\text { Merobohkan dinding ku } \\
\text { yang berjasa }\end{array}$ & $\begin{array}{l}\text { A teraz chcesz to tak łatwo } \\
\text { Zburzyć ścianę w moim } \\
\text { sercu }\end{array}$ & $\begin{array}{l}\text { A teraz Ty chcesz tak po } \\
\text { prostu zburzyć ten mur. }\end{array}$ \\
\hline $\begin{array}{l}\text { Angin kan menerpa } \\
\text { Masa depan mu }\end{array}$ & 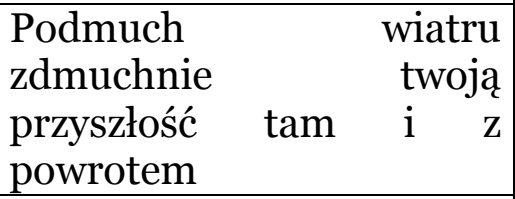 & $\begin{array}{l}\text { Twoja przyszłość nie jest } \\
\text { pewna. }\end{array}$ \\
\hline $\begin{array}{l}\text { Karena ku kan sambut } \\
\text { masa depan dengan suara } \\
\text { langka }\end{array}$ & $\begin{array}{l}\text { Bo chcę przywitać swoją } \\
\text { przyszłość głośnym i } \\
\text { otwartym głosem }\end{array}$ & $\begin{array}{l}\text { Bo chcę radośnie } \\
\text { przywitać przyszłość. }\end{array}$ \\
\hline
\end{tabular}

Nonsens spowodowany błędem frazeologicznym 
Idiom memasukan hati oznacza „wziąc sobie coś do serca”. W Biarkan Bintang Menari pojawia się on dwukrotnie i w obu przypadkach jest błędnie przetłumaczony.

Według Dzierżanowskiej (1990:32) „Tworzenie kolokacji w języku ojczystym jest czynnością instynktowną” w tym wypadku chyba instynkt zawiódł. Można „brać sobie coś do serca” lub „brać coś do siebie” nie można „brać czegoś osobiście”. Jest to błędna kolokacja.

Podobnie w drugim przypadku, można „zrozumieć coś dosłownie” więc możliwe, że od tego właśnie frazeologizmu powstało błędne „zrozumieć coś poetycko".

\begin{tabular}{|c|c|c|}
\hline Oryginal & Tłumaczenie & Powinno być \\
\hline Jangan dimasukin hati. & Nie bierz tego osobiście & Nie bierz tego do siebie. \\
\hline
\end{tabular}

\begin{tabular}{|c|c|c|}
\hline Oryginał & Tłumaczenie & Powinno być \\
\hline $\begin{array}{l}\text { Itu dimasukin hati benar } \\
\text { sama ayah. }\end{array}$ & $\begin{array}{l}\text { Mój ojciec zrozumiał to } \\
\text { poetycko }\end{array}$ & Wziął to sobie do serca. \\
\hline
\end{tabular}

\section{Nonsens wynikający z błędnej transkrypcji}

Aby stworzyć wersję polską, tłumacz miał do dyspozycji film i listę dialogową spisaną ze słuchu przez Indonezyjczyków mieszkających w Polsce. Niestety, również oni nie ustrzegli się błędów. W napisach przez nich stworzonych czytamy: Jangan bohong kayak tukang bohong Grey! Pasti kau kalah!, (tłumaczenie dosłowne: Nie kłam jak zawodowy kłamca! Na pewno przegrasz!) Podczas gdy bohater mówi:

Jangan membohongi tukang bohong Grey! Pasti kau kalah!

(tłumaczenie dosłowne: Nie okłamuj zawodowego kłamcy! Na pewno przegrasz!) Błąd w oryginale prowadzi do powstania błędu w tłumaczeniu, z czego wynika kolejny nonsens:

\begin{tabular}{|l|lr|l|}
\hline \multicolumn{1}{|c|}{ Oryginal } & \multicolumn{2}{|c|}{ Tłumaczenie } & \multicolumn{2}{c|}{ Powinno być } \\
\hline $\begin{array}{l}\text { Jangan membohongi } \\
\text { tukang bohong Grey! Pasti } \\
\text { kau kalah! }\end{array}$ & $\begin{array}{l}\text { Nie kam jak } \\
\text { profesjonalista! } \\
\text { tracisz czas! }\end{array}$ & Tylko & $\begin{array}{l}\text { Nie próbuj okłamać } \\
\text { zawodowego kłamcy! Nie } \\
\text { nabierze się! }\end{array}$ \\
\hline
\end{tabular}

\section{Inne}

\section{Wybór niewłaściwej informacji ze zdania}

Kolejnym błędem jest niewłaściwe zastosowanie pominięcia informacji z oryginalnego dialogu. Bohater mówi:

Jangan jadi ahli Ney, kamu baru selasai SMU

( Nie bądź taka przemądrzała. Dopiero skończyłaś liceum).

Ponieważ zdanie jest stosunkowo długie (36 liter) i jest poprzedzone inną długą wypowiedzią, w podpisie należało je skrócić i przekazać tylko najistotniejszą 
Daria Zozula: Analiza błędów popetnionych w ttumaczeniu indonezyjskiego musicalu „Biarkan bintang menari” na język polski.

informację. Główny nacisk jest położony na pierwszą część zdania, bohater uważa, że osoba, do której mówi, nic nie wie o życiu, a to, że dopiero skończyła liceum, ma na celu potwierdzenie tej tezy. Należało pominąć drugą część wypowiedzi, a nie, pierwszą.

\begin{tabular}{|l|l|c|}
\hline \multicolumn{1}{|c|}{ Oryginal } & \multicolumn{1}{|c|}{ Tłumaczenie } & Powinno być \\
\hline $\begin{array}{l}\text { Jangan jadi sejahtera Ney, } \\
\text { kamu baru selasai SMU }\end{array}$ & $\begin{array}{l}\text { Dopiero skończyłaś } \\
\text { liceum! }\end{array}$ & Nic nie wiesz o życiu. \\
\hline
\end{tabular}

\section{Komizm słowny i sytuacyjny}

Humor indonezyjski pozostaje nadal dla odbiorcy europejskiego niezrozumiały i mało śmieszny. Nastręcza to wiele trudności w tłumaczeniu, zwłaszcza, jeśli w grę wchodzi komizm słowny. Tłumacz nierzadko musi uciekać się do zastępowania oryginalnych dowcipów podobnymi, ale istniejącymi na gruncie kulturowym odbiorcy. Można też przetłumaczyć żart dosłownie, jeśli żart słowny nie jest jedynym czynnikiem mającym wywołać śmiech $u$ widza. W pierwszym przytoczonym fragmencie zastosowano właśnie tę technikę.

Dialog prowadzony jest między osobą, która jest przeczulona na punkcie nadużywania słowa mungkin („może”) i osobą z natręctwem nadużywania właśnie tego słowa. Tłumacz właściwie wybrał strategię, ponieważ sytuacja jest zabawna, obie postaci są komiczne, dodatkowo podkreślając humor aktorzy zabawnie modulują głos i używają języka ciała ( przesadnie groźnie zmarszczone brwi, podkreślone zmieszanie i przestrach, nerwowe rozglądanie się „na boki”, jakby w poszukiwaniu pomocy). Niestety, $\mathrm{w}$ podpisie do dialogu tłumacz pomija $\mathrm{w}$ pierwszej wypowiedzi „może”, słowo, na którym opiera się nie tylko komizm całej sytuacji, lecz także słowo, które jest pretekstem do całego dialogu. Błąd prawdopodobnie wynika z braku korekty, która powinna być dokonana zarówno przez tłumacza jak i przez osobę odpowiedzialną za korektę.

\begin{tabular}{|c|c|c|}
\hline Oryginal & Tłumaczenie & Powinno byé \\
\hline $\begin{array}{l}\text {-Ini ada teman saya juga } \\
\text { yang mungkin salah eja } \\
\text {-Mungkin?!, Ya ya, nggak } \\
\text { nggak, kok "mungkin"? }\end{array}$ & $\begin{array}{l}\text {-Mam kolegę, któremu źle } \\
\text { napisano imię. } \\
\text {-"Może"? "Tak" lub "nie", } \\
\text { nie "może"! }\end{array}$ & $\begin{array}{l}\text {-Mam kolegę, któremu } \\
\text { może źle napisano imię. } \\
\text {-"Może"? "Tak" lub "nie", } \\
\text { nie "może"! }\end{array}$ \\
\hline
\end{tabular}

Największym wyzwaniem dla tłumacza jednak zawsze pozostaje przetłumaczenie wyrażeń idiomatycznych. Bardzo często okazuje się, że w języku docelowym dany idiom nie funkcjonuje lub że w danej sytuacji nie można przetłumaczyć go deskryptywnie i nie można znaleźć jego ekwiwalentu. Taka sytuacja wystąpiła również w omawianym filmie.

Macam Kampus (dosłownie „uczelniany tygrys”) to w potocznym języku indonezyjskim określenie na uczelnianego podrywacza. Problem dodatkowo komplikuje fakt, że osoba o tym przezwisku ma na czole wielką szramę, więc koledzy przezwali go Codet Macam Kampus, czyli w wolnym tłumaczeniu „Człowiek z blizną uczelnianego podrywacza”.

Niestety, w języku polskim nie ma idiomu o podobnym wydźwięku i konotacji z blizną, na przykład funkcjonujący w języku polskim „lew salonowy” nie spełnia obu tych kryteriów. Należałoby zrezygnować z wieloznaczności tego idiomu 
i zostawić to znaczenie, które jest ważniejsze ( $\mathrm{w}$ tym wypadku jest to „podrywacz”), ponieważ kilka scen po tej następuje kolejna, w której chłopak o tym przezwisku tłumaczy się pokrętnie ze swojej sławy podrywacza i dzięki temu jest to scena komiczna. Można by też (jest to wersja proponowana przeze mnie, nie znaczy to jednak, że jest to wyjście najlepsze) stworzyć nazwisko znaczące: Zabliźniony Babilep, Harry Podrywer lub podobne.

Ostatecznie, jeśli idiom jest nieprzetłumaczalny, można zrezygnować z tłumaczenia jego wieloznaczności i podkreślenia komizmu. Tłumaczenie poniższe, czyli wprowadzenie dodatkowo trzeciego języka ( scar- ang. „blizna”) i dosłowne przetłumaczenie idiomu kolejny raz jest powodem niezrozumienia całej sytuacji przez widownię.

\begin{tabular}{|c|c|c|}
\hline Oryginał & Tłumaczenie & Powinno byé \\
\hline $\begin{array}{l}\text {-Nah, itu codet } \\
\text {-Maksudku nama } \\
\text { lengkapnya } \\
\text {-Codet Macam Kampus }\end{array}$ & $\begin{array}{l}\text {-Mówimy na niego Scar. } \\
\text {-A jego pełne imię? } \\
\text { - "Scar tygrys" }\end{array}$ & $\begin{array}{l}\text { - Mówimy na niego } \\
\text { Bliźniak } \\
\text { - A jego prawdziwe } \\
\text { nazwisko? } \\
\text { - Harry Podrywer }\end{array}$ \\
\hline \begin{tabular}{lr}
\multicolumn{1}{c}{ Kenapa } & namamu \\
sekarang & Macam \\
Kampus? & \\
\end{tabular} & $\begin{array}{l}\text {-Dlaczego mówią na ciebie } \\
\text { tygrys? }\end{array}$ & $\begin{array}{l}\text {-Dlaczego mówią na ciebie } \\
\text { Podrywer? }\end{array}$ \\
\hline
\end{tabular}


Daria Zozula: Analiza błędów popetnionych w thumaczeniu indonezyjskiego musicalu „Biarkan bintang menari” na język polski.

\section{Wprowadzenie trzeciego języka}

\begin{tabular}{|l|l|l|}
\hline Oryginal & Tłumaczenie & Powinno byé \\
\hline Jakarta hura-hura & Jakarta non-stop city & Dżakarta nie zasypia \\
\hline
\end{tabular}

Podczas tłumaczenia Biarkan Bintang Menari tłumacz miał do dyspozycji transkrypcję dialogów $\mathrm{w}$ języku indonezyjskim oraz gotowe napisy w języku angielskim. Poniższe zdanie jest częścią refrenu $\mathrm{w}$ jednej $\mathrm{z}$ piosenek, niestety $\mathrm{w}$ języku polskim nie ma odpowiednika słowa hura-hura, które jest określeniem na coś, co jest ciągle w ruchu, co podlega ciągłym zmianom, ale czego nie można traktować poważnie. Nie znajdując odpowiedniego ekwiwalentu w języku polskim tłumacz ponownie skorzystał $\mathrm{z}$ napisów angielskich i wprowadził trzeci język. Można było tego uniknąć znajdując polskie określenie, które być może nie oddawałoby całości znaczenia indonezyjskiego hura-hura, ale, co ważniejsze w tym wypadku, ponieważ jest to piosenka, wpasowywałoby się w rytm piosenki. Jakarta non stop city oczywiście nie zakłóca rytmu, określenie non-stop jest obecnie używane w niskim rejestrze polszczyzny, jednakże słowo city w tym kontekście jest nie do przyjęcia.

\section{Wprowadzenie opisu zamiast terminu}

Zamiast terminu „bajkopisarz” została wprowadzona peryfraza, czyli omówienie: „ten, który pisze bajki”, co zaowocowało zmianą znaczenia w tłumaczeniu. Z polskich napisów wynika bowiem, że ani narrator, ani ta osoba, która napisała bajkę nie mogą odpowiedzieć na to pytanie. W wersji polskiej bajkopisarz i narrator to dwie różne osoby. W oryginale natomiast jasnym jest, że narrator jest jednocześnie autorem tej bajki.

\begin{tabular}{|l|l|l|}
\hline Oryginal & Tłumaczenie & Powinno być \\
\hline $\begin{array}{l}\text { Sebagai Pendongeng saya } \\
\text { tidak mempunyai } \\
\text { jawabannya. }\end{array}$ & $\begin{array}{l}\text { Tak jak ten, który pisze } \\
\text { bajki, nie mo bajkopisarz nie mogę } \\
\text { odpowiedzieć ci na to } \\
\text { pytanie. }\end{array}$ & $\begin{array}{l}\text { odpowiedzieć na to nanie } \\
\text { pytan }\end{array}$ \\
\hline
\end{tabular}

\section{Zakończenie}

Czym są właściwie wykonane napisy filmowe? Morgan twierdzi że „dobre napisy są zgrane $\mathrm{z}$ obrazem, przekazują wszystkie intencje autora filmu w sposób jak najbliższy oryginalnemu, sprawiają wrażenie, jakby były integralną częścią filmu, a nie czymś do niego dodanym" 1 . Poza tym dobrych napisów widz nie zauważa, bo dają wrażenie, jakby widz bez pomocy tłumacza rozumiał akcję filmu.

Niestety, w omawianym wyżej filmie główną atrakcją dla widza było wyłapywanie nonsensów w napisach, których nagromadzenie było tak duże (wystąpiło 28 poważnych błędów w ciągu 145 minut filmu, co daje średnio 1 błąd

\footnotetext{
${ }^{1}$ Morgan, H R. "Good subtitles are accurately timed, and convey concisely the author's intentions in a style as close as possible to the original; they should give the impression of coming from the film rather than being imposed upon it.(..)
} 
co 5 minut), że widzowie po jakimś czasie męczyli się i w efekcie nierzadko opuszczali salę kinową. Przyczyną tej sytuacji były właśnie niskiej jakości napisy. Osoba, której zlecono wykonanie tłumaczenia od kilku lat uczyła się technik tłumaczenia, ale tłumaczenia konferencyjnego, tak przecież różnego od tłumaczenia audiowizualnego, w którym jak twierdzą Pisarska i Tomaszkiewicz (1996:192) „elementami składającymi się na sens są dialogi, obraz, muzyka, inne dźwięki oraz informacje pisane, pojawiające się na ekranie”. Poza tym obecnie w Polsce nikt nie szkoli tłumaczy polsko-indonezyjskich, a językami, w których tłumacz tego filmu pracuje, są języki: polski i niemiecki. Tłumaczowi nie zapewniono żadnego wsparcia i korekty z zewnątrz (chociaż zleceniodawca zapewniał o własnej korekcie i wizualizacji filmu z napisami, zanim odda go do dystrybucji), pliki tekstowe dostarczono w formatach, które nie były kompatybilne $\mathrm{z}$ europejskimi programami, więc przed otwarciem wymagały one konwersji. Taka sytuacja nie powinna się zdarzyć.

Dystrybutorzy, chcąc obniżyć koszty tłumaczenia, zatrudniają osoby niekompetentne, nie mające żadnego przygotowania dydaktycznego do tłumaczenia audiowizualnego i technik tłumaczeniowych $\mathrm{z}$ nim związanych. Jednocześnie, coraz więcej osób zajmujących się tłumaczeniem pisemnym lub konferencyjnym, także studentów, przyjmuje zlecenia tłumaczenia napisów filmowych, wychodząc z założenia, że nie jest to niczym skomplikowanym, skoro Internet pełen jest napisów, których autorami są „amatorzy”, nie wiedząc, że tak naprawdę, ci tak zwani amatorzy działają $\mathrm{w}$ dobrze zorganizowanych grupach, podobnych do zespołów profesjonalnych tłumaczy audiowizualnych. W tym błędnym przekonaniu tkwią nie tylko początkujący tłumacze ale, co gorsza również zleceniodawcy. Prowadzi to do powstania tłumaczeń o niskiej cenie, ale też o niskiej jakości.

Korpus:

Biarkan Bintang Menari (Gwiazdy grają o miłość) - reż. Indra Yudhistira. 
Daria Zozula: Analiza błędów popetnionych w ttumaczeniu indonezyjskiego musicalu „Biarkan bintang menari” na język polski.

\section{Bibliografia:}

Chaer A., 2003. Linguistik Umum. Jakarta: Penerbit Rineka Cipta.

Delisle, J. 2004. Terminologia thumaczenia. Poznań: Wydawnictwo Naukowe UAM (tłum. Teresa Tomaszkiewicz)

Dzierżanowska, H. 1990. Przekład tekstów nieliterackich. Warszawa: Państwowe Wydawnictwo Naukowe.

Echols, M., Shadily H. 1989. Kamus Indonesia Inggris. Wydanie Ósme, Jakarta: Penerbit PT Gramedia

Echols, M. Shadily H.1989. Kamus Inggris Indonesia. Wydanie Ósme, Jakarta: Penerbit PT Gramedia

Fang, L. Y. 2004. Indonesian Gramar Made Easy. Singapur: Times Editions.

Farst P. i inni, 1999. Krytyka przekładu $w$ systemie wiedzy o literaturze. Katowice: Wydawnictwo Śląsk

Farst P., Janikowski P. i inni, 2006 . Dialog czy nieporozumienie? Katowice: Wydawnictwo Śląsk

Gambier Y., Gottlien H. i inni, 2001. (Multi) Media Translation. Amsterdam: John Benjamins publishing company.

Grucza, F. 1978. Z problematyki błędów obcojęzycznych. Warszawa: Wydawnictwa Szkolne i Pedagogiczne

Kopczyński A. 1980. Conference Interpreting - some linguistic and comunicative problems. Poznań: Wydawnictwo Naukowe UAM.

Lukszyn, J. 1993. Tezaurus terminologii translatorycznej. Warszawa: Wydawnictwo Naukowe PWN.

Neuger L. 1997. Z perspektywy ttumacza. Kraków: Oficyna literacka.

Nowak P. 2006. Analiza btędów w przekładzie unijnych aktów normatywnych na przyktadzie Cuoncil Regulation (EC) no 1346/20oo of 29th May 2000 on Insolvency Proceedings., Investigationes Linguisticae Vol. XIII, December 2006

Oreiro P., 2004. Topics In Audiovisual Translation. Amsterdam: John Benjamins publishing company.

Pisarska A. Tomaszkiewicz T., 1996. Wspótczesne teorie przekładoznawcze. Poznań: Wydawnictwo Naukowe UAM.

Tabakowska E., 1999. O przekładzie na przykładzie. Kraków: Wydawnictwo Znak

Tomaszkiewicz T., 2006. Przekład audiowizualny. Warszawa: Wydawnictwo Naukowe PWN

Wojtasiewicz O. 1996, Wstęp do teorii thumaczenia. (reprint z 1957). Warszawa: TEPIS 